\title{
ANALISIS PERAMALAN PENJUALAN PRODUK SUPLEMEN PT. GREEN WORLD GLOBAL PADA E-MARKETPLACE
}

\author{
Andi Nur Rahman ${ }^{1, a)}$ Gerry Sastro ${ }^{2, b)}$ \\ ${ }^{1}$ Program Studi Matematika FMIPA Universitas Pamulang \\ ${ }^{2}$ Program Studi Matematika FMIPA Universitas Pamulang \\ Email: ${ }^{a)}$ dosen00700@unpam.ac.id ${ }^{\text {b) }}$ dosen00544@unpam.ac.id
}

\begin{abstract}
ABSTRAK
Peramalan merupakan hal sangat penting dalam dunia usaha untuk mengetahui kelajutan diwaktu mendatang. Tujuan penelitian ini yaitu untuk mengetahui Bagaimana pola data penjualan produk suplemen Green World pada e-marketplace dari Januari 2016 - Juli 2017, untuk mengetahui metode peramalan kuantitatif apakah yang paling sesuai untuk meramalkan jumlah penjualan produk suplemen Green World pada $e$ marketplace dari Januari 2016 sampai Juli 2017, dan untuk mengetahui peramalan penjualan produk suplemen Green World pada e-marketplace untuk 15 bulan mendatang dengan menggunakan metode kuantitatif terbaik. Metode penelitian yaitu metode survei. Hasil penelitian yaitu pola data penjualan tren naik. Analisis penjualan keseluruhan penjualan pada e-marketplace lebih sesuai dengan metode peramalan Penghalusan Eksponensial Ganda (Double Exponentian Smoothing) yang memiliki nilai MSE terkecil $(50,0011)$ dibandingkan dengan metode peramalan lainnya. Hasil peramalan penjualan produk suplemen Green World pada e-marketplace dari Januari 2016 sampai Juli 2017 cukup bervariasi. Peramalan penjualan pada tokopedia dan bukalapak mengalami peningkatan dimana hasil ramalan tertinggi terdapat pada periode 15 dengan penjualan 31 produk di tokopedia dan 28 produk di bukalapak. Ramalan penjualan di blibli menunjukkan angka yang tetap dari periode 1 hingga 15 yaitu 17 produk. Hasil ramalan penjualan secara keseluruhan pada e-marketplace mengalami peningkatan dimana hasil ramalan tertinggi terdapat pada periode 15 dengan penjualan 81 produk.
\end{abstract}

Kata kunci: Eksponensial Ganda, pola data

\section{ABSTRACT}

Forecasting is very important in the business world to know the continuity in the future. The aims of this study is to find out how data patterns of Green World supplement product sales in e-marketplaces from January 2016 - July 2017, to find out what quantitative forecasting methods are most suitable for predicting the number of Green World supplement product sales on e-marketplaces from January 2016 to July 2017, and to find out sales forecast of Green World supplement products in the e-marketplace for the next 15 months using the best quantitative methods. The research method is the survey method. The results of the research are data patterns of rising trend sales. Analysis of the overall sales of sales in the e-marketplace is more in line with the Double Exponentiation Smoothing forecasting method which has the smallest MSE value (50,0011) compared to other forecasting methods. Forecasting results from the 
sale of Green World supplement products on e-marketplaces from January 2016 to July 2017 are quite varied. Sales forecasting at Tokkopedia and Bukalapak has increased where the highest forecast results are in the 15th period with sales of 31 products at Tokopedia and 28 products at Bukalapak. Sales forecasts on Blibli show a fixed number from periods 1 to 15 , namely 17 products. Overall sales forecast results on the emarketplace have increased where the highest forecast results are in period 15 with sales of 81 products.

Keywords: Multiple Exponentials, data patterns

\section{PENDAHULUAN}

\subsection{Latar Belakang}

Perkembangan dalam era globalisasi berjalan dengan pesat. Inovasi-inovasi baru terus dilahirkan guna mempermudah pekerjaan manusia. Dalam bidang teknologi dan informasi ditandai dengan adanya jaringan internet yang saat ini telah tersebar ke seluruh dunia. Pengguna internet dari hari ke hari semakin meningkat, bahkan internet telah dijadikan sebagai gaya hidup. Semua aktivitas sehari-hari yang dilakukan tidak terlepas dari internet, tak terkecuali dalam melakukan aktivitas jual-beli. Prosedur berdagang atau mekanisme jual-beli di internet ini biasanya disebut E-commerce (Electronic Commerce). E-commerce didefinisikan sebagai proses pembelian dan penjualan antara dua belah pihak di dalam suatu perusahaan dengan adanya pertukaran barang, jasa, atau informasi melaui media internet.

Ternyata tidak mudah dalam mengimplementasikan e-commerce dikarenakan banyaknya faktor yang terkait dan teknologi yang harus dikuasai. Dengan demikian ada tiga kategori dasar atau jenis-jenis e-commerce yaitu Businness to Consumer (B2C), Businness to Businness (B2B) dan Consumer to Consumer (C2C).

Perkembangan internet yang semakin maju merupakan salah satu faktor pendorong berkembangnya e-commerce. Perkembangan e-commerce membawa banyak perubahan terhadap sektor aktivitas bisnis yang selama ini dijalankan di dunia nyata. Kemajuan teknologi ini juga memudahkan perusahaan dalam bertransaksi dengan konsumen, konsumen tidak perlu bertemu secara langsung dengan pihak perusahaan seperti halnya datang ke mall/toko, cukup dengan menggunakan internet transaksi dapat dilakukan dimana saja dan kapan saja. Selain itu, pengusaha dapat menjangkau target pasar yang jauh lebih luas dengan biaya yang lebih murah jika dibandingkan dengan menggunakan cara biasa secara offline.

Salah satu jenis e-commerce yang saat ini mulai berkembang pesat di Indonesia adalah e-commerce jenis e-marketplace. E-marketplace yang ada di Indonesia 
diantaranya yaitu tokopedia.com, bukalapak.com, blibli.com, zalora, elevenia, lazada, dan sebagainya.

E-marketplace merupakan bagian dari e-commerce. Menurut Brunn, Jensen, \& Skovgaard (2002), e-marketplace adalah wadah komunitas bisnis interaktif secara elektronik yang menyediakan pasar dimana perusahaan dapat ambil andil dalam B2B $e$ commerce dan atau kegiatan e-business lain. E-marketplace dapat dikatakan sebagai gelombang kedua pada e-commerce dan memperluas kombinasi dari bisnis konsumen (B2B, C2B dan C2C) ke dalam B2B. Inti penawaran dari e-marketplace adalah mempertemukan pembeli dan penjual sesuai dengan kebutuhan dan menawarkan efisiensi dalam bertransaksi.

Penggunaan e-marketplace pada perusahaan berdampak positif bagi beberapa aspek. PT. Green World Global sebagai salah satu perusahaan penyedia produk suplemen herbal kini juga sudah merambah ke penjualan online. Ada banyak anggota dari Green World yang mulai menjual produk pada $e$-marketpalce.

Atas dasar latar belakang diatas, penulis melakukan analisa sistematis tentang penjualan produk suplemen Green World pada e-marketplace yang dilakukan di Stokis Alam Sutera. Dengan data yang diperoleh dari Stokis Green World Alam Sutera dari bulan Januari 2016 dengan menggunakan metode peramalan.

\subsection{Rumusan Masalah}

Sesuai dengan latar belakang diatas, maka permasalahan yang akan dibahas dalam laporan ini adalah:

1. Bagaimana pola data penjualan produk suplemen Green World pada $e$ marketplace dari Januari 2016 sampai Juli 2017 ?

2. Bentuk metode peramalan kuantitatif apakah yang paling sesuai untuk meramalkan jumlah penjualan produk suplemen Green World pada $e$ marketplace dari Januari 2016 sampai Juli 2017 ?

3. Bagaimana peramalan penjualan produk suplemen Green World pada $e$ marketplace untuk 15 bulan mendatang dengan menggunakan metode kuantitatif terbaik?

\subsection{Tujuan Penelitian}

Tujuan dari penulisan laporan kerja praktek ini adalah sebagai berikut:

1. Untuk mengetahui Bagaimana pola data penjualan produk suplemen Green World pada e-marketplace dari Januari 2016 - Juli 2017. 
2. Untuk mengetahui metode peramalan kuantitatif apakah yang paling sesuai untuk meramalkan jumlah penjualan produk suplemen Green World pada $e$ marketplace dari Januari 2016 sampai Juli 2017.

3. Untuk mengetahui peramalan penjualan produk suplemen Green World pada e-marketplace untuk 15 bulan mendatang dengan menggunakan metode kuantitatif terbaik.

\section{METODOLOGI PENELITIAN}

\subsection{Metode Rataan Bergerak (Moving Average)}

Moving Average adalah model time series yang melihat pergerakan melalui residual di masa lalu. Dalam moving average data diperhalus dengan membuat rata-rata secara berurutan dari sekelompok pengamatan pada jangka waktu tertentu. Rataan bergerak berguna, jika diasumsikan permintaan pasar akan stabil sepanjang masa yang diramalkan.

Tujuan utama dari penggunaan rataan bergerak adalah untuk menghilangkan atau mengurangi acakan (randomness) dalam deret berkala. Metode ini disebut rata - rata bergerak karena setiap kali data observasi baru tersedia, maka angka - angka baru dihitung dan digunakan sebagai ramalan (forecast) untuk periode yang akan datang.

Metode moving average mengembangkan suatu model berdasarkan hasil perhitungan rata-rata dari sebagian besar penelitian. Secara matematik, rataan bergerak sederhana (merupakan prediksi permintaan periode mendatang) dinyatakan sebagai berikut :

$$
F_{t}=\frac{1}{n}\left(A_{t-1}+A_{t-2}+\ldots+A_{t-n}\right)
$$

dimana :

$\mathrm{F}_{\mathrm{t}} \quad=$ Hasil peramalan untuk periode $\mathrm{t}$

$n \quad=$ jumlah data penelitian

$\mathrm{A}_{\mathrm{t}} \quad=$ data histori penjualan

a. Keuntungan dari metode rataan bergerak yaitu:

1) Mudah untuk dimengerti

2) Mudah untuk dihitung

3) Dapat diterapkan untuk peramalan yang stabil

b. Kekurangan dari metode rataan bergerak yaitu:

1) Dibutuhkan beberapa/banyak data yang digunakan untuk menentukan peramalan

2) Hasil yang diperoleh merupakan trend data

3) Mengabaikan hubungan antar data 


\subsection{Metode Penghalusan Eksponensial (exponential smoothing)}

Penghalusan Eksponensial (exponential smoothing) merupakan metode peramalan rataan bergerak dengan pembobotan canggih, namun masih mudah digunakan. Metode ini menggunakan sangat sedikit pencatatan data masa lalu.

Metode ini merupakan metode peramalan yang menerapkan sistem pembobotan pada data histori untuk melakukan peramalan. Besarnya bobot berubah menurun secara eksponensial bergantung dari data histori

Berdasarkan bobot yang digunakan, metode exponential smoothing terbagi menjadi 3 jenis yaitu:

\section{Metode single exponential smoothing}

Metode ini memberikan bobot berdasarkan level $(\alpha)$, dimana $\alpha$ adalah sebuah bobot atau konstanta penghalusan (smoothing constant) yang dipilih oleh peramal, yang mempunyai nilai antara 0 dan 1 . Berikut ini merupakan persamaan dari metode single exponential smoothing (Jacob, 2009):

$$
F_{t}=F_{t-1}+\alpha\left(A_{t-1}-F_{t-1}\right)
$$

dimana :

$$
\begin{array}{ll}
\mathrm{F}_{\mathrm{t}} & =\text { peramalan baru } \\
\mathrm{F}_{\mathrm{t}-1} & =\text { peramalan sebelumnya } \\
\alpha & =\text { konstanta penghalus } \\
\mathrm{A}_{\mathrm{t}-1} & =\text { permintaan aktual periode lalu }
\end{array}
$$

2. $\quad$ Metode double exponential smoothing

Metode ini merupakan pengembangan dari single exponential smoothing dimana menambahkan unsur trend pada bobot perhitungan, sehingga pada double exponential smoothing, kita memberikan dua jenis bobot pada perhitungan yaitu level $(\alpha)$ dan trend (B). Berikut ini merupakanpersamaan dalam perhitungan double exponentialsmoothing (Jacob, 2009):

$$
\begin{array}{ll}
\text { FIT }_{\mathrm{t}} & =\mathrm{F}_{\mathrm{t}}+\mathrm{T}_{\mathrm{t}} \ldots \ldots \ldots \ldots \ldots \ldots \ldots \ldots \ldots \ldots \ldots \ldots \ldots \ldots \ldots \\
\mathrm{F}_{\mathrm{t}} & =\mathrm{FIT}_{\mathrm{t}-1}+\alpha\left(\mathrm{A}_{\mathrm{t}-1}-\mathrm{FIT}_{\mathrm{t}-1}\right) \\
\mathrm{T}_{\mathrm{t}} & =\mathrm{T}_{\mathrm{t}-1}+\beta\left(\mathrm{F}_{\mathrm{t}}-\text { FIT }_{\mathrm{t}-1}\right) \ldots \ldots . .
\end{array}
$$

dimana,

$\mathrm{F}_{\mathrm{t}} \quad=$ peramalan berdasarkan level pada periode $\mathrm{t}$

$\mathrm{T}_{\mathrm{t}} \quad=$ peramalan berdasarkan trend pada periode $\mathrm{t}$

FITt =hasil peramalan berdasarkan level dan trend pada periode $\mathrm{t}$

FIT t-1 =hasil peramalan berdasarkan level dan trend pada periode sebelumnya 


$$
\begin{array}{ll}
\mathrm{A}_{\mathrm{t}-1} & =\text { data aktual pada periode sebelumnya } \\
\alpha & =\text { bobot level } \\
\beta & =\text { bobot trend }
\end{array}
$$

\subsection{Waktu Penelitian}

Pelaksanaan penelitian dilaksanakan di Stokis Green World Alam Sutera pada tanggal 10 Juli - 11 Agustus 2017. Perhitungan jam kerja disesuaikan dengan jam kerja stokis yaitu setiap hari Senin - Jumat, jam 09.00 - 17.00 WIB.

\subsection{Tempat Penelitian}

Pelaksanaan penelitian dilaksanakan di Stokis Green World Alam Sutera yang beralamat di Cluster Sutera Cemara VI no. 2 Alam Sutera, Serpong, Tangerang Selatan, Banten. Stokis Green World Alam Sutera merupakan salah satu stokis yang beroperasi di bawah naungan PT. Green World Global Indonesia.

\subsection{Populasi dan Sampel}

\subsubsection{Populasi Penelitian}

Populasi yang dipilih sebagai obyek penelitian di PT. Green World Global Indonesia adalah penjualan produk Green World pada $e$-marketplace.

\subsubsection{Sampel Penelitian}

Dalam penelitian ini diambil data penjualan dari Stokis Green World Alam Sutera yang menggunakan dan mengelola 3 e-marketplace yaitu tokopedia.com, bukalapak.com, dan blibli.com.

\subsection{Metode Pengumpulan Data}

Data yang digunakan adalah data historis penjualan produk Green World pada $e$ marketplace. Data penjualan yang digunakan adalah data penjualan produk Green World pada e-marketplace dengan penyebaran dari bulan Januari 2016 - Juli 2017.

Informasi dan pengumpulan data yang dikumpulkan meliputi data primer dan sekunder. Data primer merupakan data yang didapat dari sumber utama, individu atau perseorangan, seperti dari hasil analisa dan pengamatan langsung di lapangan, serta wawancara langsung dengan pihak manajemen perusahaan sebagai narasumber. Sedangkan data sekunder merupakan data primer yang diperoleh pihak lain atau telah diolah dan disajikan baik oleh pengumpul data primer maupun oleh pihak lain, atau data pelengkap dari data primer yang dikumpulkan dari literatur-literatur, studi pustaka atau laporan internal perusahaan (data penjualan produk Green World dari bulan Januari 
2016 - Juli 2017), kebijakan dan peraturan perusahaan (sejarah umum perusahaan, visi dan misi perusahaan) baik itu berupa laporan bulanan dan tahunan manajemen perusahaan ataupun tulisan yang berkaitan dengan penjualan dan pemasaran produk Green World.

\subsection{Metode Pengolahan Data}

Pengolahan dan analisis data yang digunakan dalam penelitian dilakukan secara kualitatif dan kuantitatif. Analisis kualitatif menggabungkan faktor-faktor seperti intuisi pengambil keputusan, emosi, pengalaman pribadi dan sistem nilai. Analisis kualitatif menggambarkan keadaan umum perusahaan dan mengetahui permasalahan yang terjadi dalam usaha tersebut. Sedangkan analisis kuantitatif menggunakan model matematik yang beragam dengan data masa lalu dan peubah sebab akibat untuk meramalkan permintaan.

Analisis kuantitatif yang dilakukan untuk analisis peramalan penjualan produk Green World pada e-marketplace selama 15 periode mendatang di Stokis Alam Sutera menggunakan beberapa metode peramalan time series dengan pertimbangan data penjualan adalah deret waktu, artinya disajikan berdasarkan waktu kejadian tanpa menunjukkan faktor-faktor yang mempengaruhinya, yaitu metode Exponential Smoothing dan metode Moving Average. Hasil peramalan tersebut digunakan untuk menetapkan target penjualan produk Green World pada e-marketplace dan dapat dijadikan acuan perusahaan untuk menyususun perencanaan produksi terbaik di masa mendatang. Data kuantitatif tersebut diolah dengan menggunakan software Minitab18.

Peramalan penjualan produk Green World pada $e$-marketplace dapat diidentifikasi melalui pemetaan data dan pemetaan autokorelasi, yang kemudian ditabulasikan dalam bentuk tabel dan kurva dengan menggunakan Minitab18. Dengan melakukan plot data tersebut dapat diketahui pemetaan data penjualan sementara, sehingga diketahui apakah data tersebut memiliki unsur trend, siklus atau musiman, karena berguna untuk menduga sementara metode peramalan yang digunakan.

Menurut Heizer dan Render (2006), mempunyai empat (4) komponen, yaitu tren, musim, siklus dan variasi acak (random variation).

1. Tren merupakan pergerakan data sedikit demi sedikit meningkat atau menurun. Perubahan pendapatan, populasi, penyebaran umur, atau pandangan budaya dapat mempengaruhi pergerakan tren.

2. Musim adalah pola data yang berulang pada kurun waktu tertentu seperti hari, minggu, bulan, atau kuartal.

3. Siklus adalah pola dalam data yang terjadi setiap beberapa tahun. Siklus ini biasanya terkait pada siklus bisnis dan merupakan satu hal penting dalam analisis dan perencanaan bisnis jangka pendek. Memprediksi siklus bisnis sulit, karena dipengaruhi oleh kejadian politik ataupun kerusuhan internasional. 
4. Variasi acak merupakan satu titik khusus dalam data yang disebabkan oleh peluang dan situasi yang tidak biasa. Variasi acak tidak mempunyai pola khusus, jadi tidak dapat diprediksi.

Menurut Handoko (1984), metode time series merupakan metode peramalan runtut waktu mencoba untuk meramalkan kejadian-kejadian di waktu mendatang atas dasar serangkaian masa lalu. Serangkaian data ini merupakan serangkaian observasi sebagai peubah menurut waktu dan biasanya ditabulasi, serta digambarkan dalam bentuk grafik yang menunjukkan peubah subyek. Komponen-komponen time series pada umumnya diklasifikasikan sebagai Trend (T), Musiman atau seasional (M), Siklikal atau cyclical (S) dan residu atau eratic (E).

Pemilihan metode peramalan time series dilakukan sesuai dengan data penjualannya. Metode yang dipilih adalah metode yang sesuai dan tepat, yaitu dalam menilai seberapa jauh model menghasilkan sebuah ramalan yang tak jauh berbeda dengan keadaan aktual.

Keakuratan keseluruhan peramalan dapat dilihat dari membandingkan nilai yang diramal dengan nilai aktual. Ada beberapa perhitungan yang digunakan untuk menghitung kesalahan peramalan total, yaitu simpangan rataan absolut (MAD), kesalahan rataan kuadrat (MSE) dan kesalahan persen rataan absolut (MAPE).

$\operatorname{MAD}=\left[\sum\left(\mathrm{A}_{\mathrm{t}}-\mathrm{F}_{\mathrm{t}}\right)\right] / \mathrm{n}$

$\operatorname{MSE} \quad=\left[\sum\left(\mathrm{A}_{\mathrm{t}}-\mathrm{F}_{\mathrm{t}}\right)^{2}\right] / \mathrm{n}$

MAPE $\left.=\left[\sum\left(\mathrm{A}_{\mathrm{t}}-\mathrm{F}_{\mathrm{t}}\right) / \mathrm{A}_{\mathrm{t}}\right)\right] / \mathrm{n}$

dimana :

$$
\begin{array}{ll}
\mathrm{A}_{\mathrm{t}} & =\text { nilai aktual } \\
\mathrm{F}_{\mathrm{t}} & =\text { nilai ramalan } \\
\left(\mathrm{A}_{\mathrm{t}}-\mathrm{F}_{\mathrm{t}}\right) & =\text { kesalahan ramalan (galat) } \\
\mathrm{n} & =\text { banyaknya data }
\end{array}
$$

Prosedur peramalan dengan metode time series (Baroto, 2002) adalah :

1. Tentukan pola data penjualan, dengan memetakan data secara grafis dan menyimpulkan apakah data itu berpola trend, musiman, siklikal, atau eratik/acak.

2. Mencoba beberapa metode time series yang sesuai dengan pola penjualan tersebut untuk melakukan peramalan. Metode yang dicoba semakin banyak, maka semakin baik. Pada setiap metode, sebaiknya dilakukan peramalan dengan parameter berbeda.

3. Mengevalusi tingkat kesalahan masing-masing metode yang telah dicoba. Tingkat kesalahan diukur dengan kriteria MAD, MSE, MAPE, atau lainnya. Sebaiknya nilai tingkat kesalahan (MAD, MSE, atau MAPE) ditentukan 
dulu. Dalam hal ini, tidak ada ketentuan mengenai berapa tingkat kesalahan maksimal dalam peramalan.

4. Memilih metode terbaik diantara metode yang dicoba. Metode terbaik adalah metode yang memberikan tingkat kesalahan terkecil dibandingkan metode lainnya dan tingkat kesalahan tersebut di bawah batas tingkat kesalahan yang ditetapkan.

5. Melakukan peramalan dengan metode terbaik yang telah dipilih.

Pemetaan autokorelasi dilakukan dengan menunjukkan keeratan hubungan antara nilai peubah yang sama pada periode waktu berbeda.

1. Apabila nilai koefisien autokorelasi pada time lag dua atau tiga periode tidak berbeda nyata dari nol, maka data tersebut adalah data stasioner.

2. Apabila nilai koefisien autokorelasi pada beberapa time lag pertama secara berurutan berbeda nyata dari nol, maka data tersebut adalah data yang menunjukkan pola trend.

3. Apabila nilai koefisien pada beberapa time lag yang mempunyai jarak sistematis berbeda nyata dari nol, maka data tersebut adalah data komponen musiman.

\subsubsection{Metode Rataan Bergerak}

Metode rataan sederhana menggunakan semua data tersedia dan cocok meramalkan data time series dengan data stasioner.

\subsubsection{Metode Penghalusan Eksponensial}

Penghalusan Eksponensial (exponential smoothing) merupakan metode peramalan rataan bergerak dengan pembobotan canggih, namun masih mudah digunakan. Metode ini menggunakan sedikit pencatatan data masa lalu. Rumus penghalusan eksponensial dibagi menjadi:

1. Metode penghalusan eksponensial tunggal

Metode yang menyediakan rataan bergerak tertimbang secara eksponensial semua nilai pengamatan yang lalu (Hanke, et al., 2003).

2. Metode penghalusan eksponensial ganda

Hal ini merupakan metode linear satu (1) parameter dari Brown (double exponential smoothing). 


\section{HASIL DAN PEMBAHASAN}

\subsection{Hasil Data Penelitian}

Data yang digunakan adalah data penjualan produk Green World pada tiga (3) $e$ marketplace di Stokis Alam Sutera dari bulan Januari 2016 sampai Juli 2017. Emarketplace yang digunakan yaitu tokopedia.com, bukalapak.com, dan blibli.com. Data yang digunakan sebanyak 19 data.

Tabel 3.1 Data Penjualan Produk Green World pada e-marketplace

\begin{tabular}{|c|c|c|c|c|c|}
\hline Tahun & Bulan & Tokopedia.com & Bukalapak.com & Blibli.com & Total \\
\hline \multirow{12}{*}{$\frac{0}{\stackrel{0}{c}}$} & Jan & 10 & 5 & 3 & 18 \\
\hline & Feb & 8 & 10 & 6 & 24 \\
\hline & Mar & 12 & 11 & 8 & 31 \\
\hline & Apr & 21 & 12 & 4 & 37 \\
\hline & Mei & 13 & 11 & 3 & 27 \\
\hline & Jun & 16 & 10 & 12 & 38 \\
\hline & Jul & 17 & 8 & 15 & 40 \\
\hline & $\mathrm{Ags}$ & 12 & 9 & 21 & 42 \\
\hline & Sept & 13 & 11 & 22 & 46 \\
\hline & Okt & 11 & 8 & 24 & 43 \\
\hline & Nov & 13 & 13 & 29 & 55 \\
\hline & Des & 17 & 9 & 29 & 55 \\
\hline \multirow{7}{*}{$\bar{\delta}$} & Jan & 11 & 10 & 26 & 47 \\
\hline & Feb & 28 & 20 & 16 & 64 \\
\hline & Mar & 16 & 20 & 17 & 53 \\
\hline & Apr & 25 & 15 & 26 & 66 \\
\hline & Mei & 21 & 18 & 16 & 55 \\
\hline & Jun & 19 & 13 & 18 & 50 \\
\hline & Jul & 19 & 19 & 15 & 53 \\
\hline \multicolumn{2}{|c|}{ Jumlah } & 302 & 232 & 310 & 844 \\
\hline
\end{tabular}




\subsection{Hasil Perhitungan}

\subsubsection{Hasil Perhitungan pada Tokopedia}

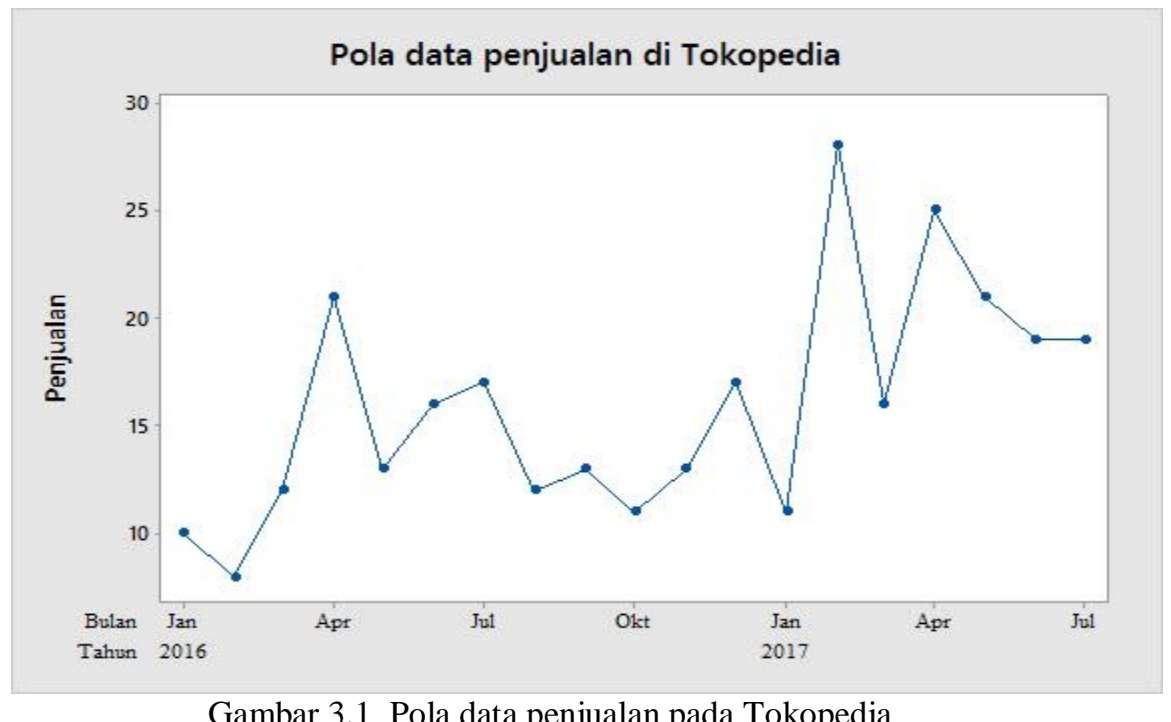

Gambar 3.1 Pola data penjualan pada Tokopedia

Tabel 3.2 Analisa Kesalahan Peramalan Penjualan di Tokopedia

\begin{tabular}{|c|c|c|c|}
\hline Metode & MAD & MSE & MAPE \\
\hline Rataan Bergerak (Moving Average) & 3,7083 & 27,9306 & 20,0195 \\
\hline $\begin{array}{c}\text { Penghalusan Eksponensial Tunggal } \\
\text { (Single Exponentian Smoothing) }\end{array}$ & 3,3996 & 24,8526 & 20,5612 \\
\hline $\begin{array}{c}\text { Penghalusan Eksponensial Ganda } \\
\text { (Double Exponentian Smoothing) }\end{array}$ & 3,6168 & 22,9827 & 22,8647 \\
\hline
\end{tabular}

Berdasarkan Tabel 4.2, penjualan produk suplemen Green World pada tokopedia yang dianalisis dengan Minitab 18 dengan metode peramalan Penghalusan Eksponensial Ganda (Double Exponentian Smoothing) memiliki nilai MSE terkecil $(22,9827)$ dibandingkan dengan metode peramalan lainnya.

Peramalan penjualan suplemen Green World untuk 15 periode kedepan di tokopedia, dianalisis menggunakan metode peramalan Penghalusan Eksponensial Ganda (Double Exponentian Smoothing). 
Tabel 3.3 Ramalan penjualan produk suplemen Green World pada tokopedia dengan metode Double Exponentian Smoothing

\begin{tabular}{|c|l|c|}
\hline Periode & \multicolumn{1}{|c|}{ Bulan } & Peramalan Penjualan \\
\hline 20 & Agustus 2017 & 21,6199 \\
\hline 21 & September 2017 & 22,22642 \\
\hline 22 & Oktober 2017 & 22,83293 \\
\hline 23 & November 2017 & 23,43944 \\
\hline 24 & Desember 2017 & 24,04596 \\
\hline 25 & Januari 2018 & 24,65247 \\
\hline 26 & Februari 2018 & 25,25898 \\
\hline 27 & Maret 2018 & 25,86549 \\
\hline 28 & April 2018 & 26,47201 \\
\hline 29 & Mei 2018 & 27,07852 \\
\hline 30 & Juni 2018 & 27,68503 \\
\hline 31 & Juli 2018 & 28,29155 \\
\hline 32 & Agustus 2018 & 28,89806 \\
\hline 33 & September 2018 & 29,50457 \\
\hline 34 & Oktober 2018 & 30,11109 \\
\hline
\end{tabular}

\subsubsection{Hasil Perhitungan pada Bukalapak}

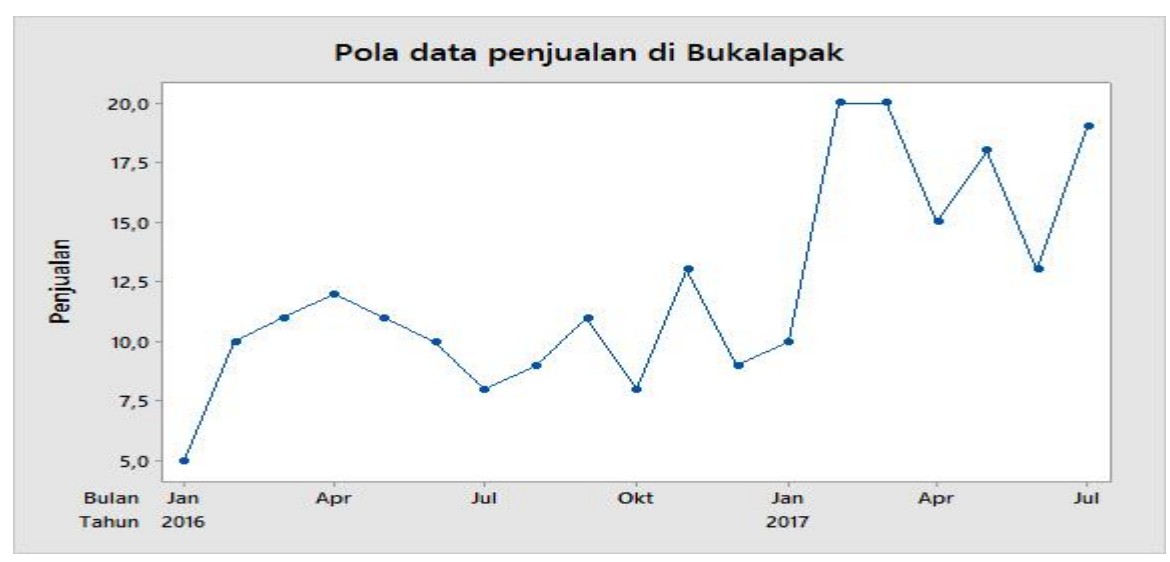

Gambar 3.2 Pola data penjualan pada Bukalapak

Berdasarkan data penjualan pada bukalapak, dilakukan identifikasi kesalahan peramalan dengan metode rataan bergerak (moving average), penghalusan eksponensial tunggal (single exponential smoothing), dan penghalusan eksponensial ganda (double exponential smoothing). Perhitungan masing-masing metode dengan menggunakan software MINITAB 18 terdapat pada Lampiran. 
Tabel 3.4 Analisa Kesalahan Peramalan Penjualan di Bukalapak

\begin{tabular}{|l|c|c|c|}
\hline \multicolumn{1}{|c|}{ Metode } & MAD & MSE & MAPE \\
\hline Rataan Bergerak (Moving Average) & 2,7292 & 13,6597 & 19,8385 \\
\hline $\begin{array}{l}\text { Penghalusan Eksponensial Tunggal } \\
\text { (Single Exponentian Smoothing) }\end{array}$ & 2,7618 & 14,1579 & 22,6067 \\
\hline $\begin{array}{l}\text { Penghalusan Eksponensial Ganda } \\
\text { (Double Exponentian Smoothing) }\end{array}$ & 2,7903 & 11,6920 & 24,4495 \\
\hline
\end{tabular}

Berdasarkan Tabel 4.4, penjualan produk suplemen Green World pada tokopedia yang dianalisis dengan Minitab 18 dengan metode peramalan Penghalusan Eksponensial Ganda (Double Exponentian Smoothing) memiliki nilai MSE terkecil $(11,6920)$ dibandingkan dengan metode peramalan lainnya.

Peramalan penjualan suplemen Green World untuk 15 periode kedepan di tokopedia, dianalisis menggunakan metode peramalan Penghalusan Eksponensial Ganda (Double Exponentian Smoothing).

Tabel 3.5 Ramalan penjualan produk suplemen Green World pada bukalapak dengan metode Double Exponentian Smoothing

\begin{tabular}{|c|l|c|}
\hline Periode & \multicolumn{1}{|c|}{ Bulan } & Peramalan Penjualan \\
\hline 20 & Agustus 2017 & 18,1368 \\
\hline 21 & September 2017 & 18,8174 \\
\hline 22 & Oktober 2017 & 19,4980 \\
\hline 23 & November 2017 & 20,1787 \\
\hline 24 & Desember 2017 & 20,8593 \\
\hline 25 & Januari 2018 & 21,5399 \\
\hline 26 & Februari 2018 & 22,2206 \\
\hline 27 & Maret 2018 & 22,9012 \\
\hline 28 & April 2018 & 23,5818 \\
\hline 29 & Mei 2018 & 24,2624 \\
\hline 30 & Juni 2018 & 24,9431 \\
\hline 31 & Juli 2018 & 25,6237 \\
\hline 32 & Agustus 2018 & 26,3043 \\
\hline 33 & September 2018 & 26,9850 \\
\hline 34 & Oktober 2018 & 27,6656 \\
\hline
\end{tabular}




\subsubsection{Hasil Perhitungan pada Blibli}

Berdasarkan data penjualan pada blibli, dilakukan identifikasi kesalahan peramalan dengan metode rataan bergerak (moving average), penghalusan eksponensial tunggal (single exponential smoothing), dan penghalusan eksponensial ganda (double exponential smoothing). Perhitungan masing-masing metode dengan menggunakan software MINITAB 18 terdapat pada Lampiran.

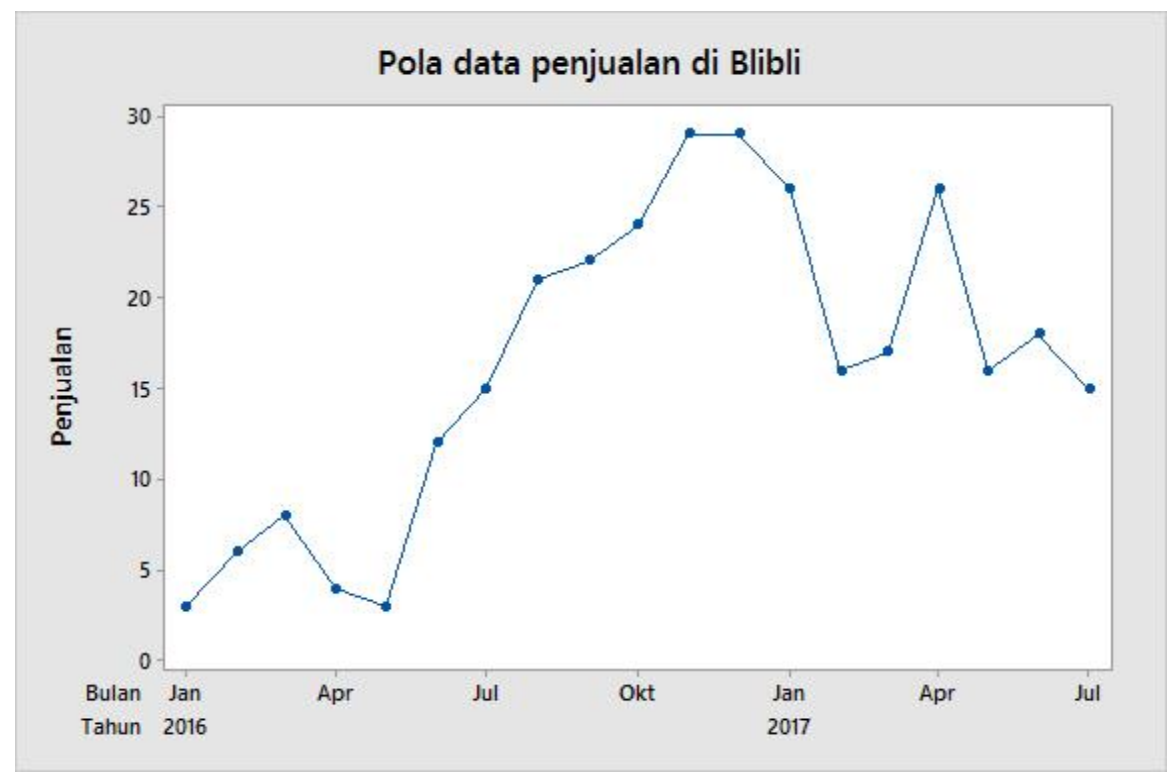

Gambar 3.3 Pola data penjualan pada Blibli

Tabel 3.6 Analisa Kesalahan Peramalan Penjualan di Blibli

\begin{tabular}{|l|c|c|c|}
\hline \multicolumn{1}{|c|}{ Metode } & MAD & MSE & MAPE \\
\hline Rataan Bergerak (Moving Average) & 5,5833 & 40,4167 & 37,679 \\
\hline $\begin{array}{l}\text { Penghalusan Eksponensial Tunggal (Single } \\
\text { Exponentian Smoothing) }\end{array}$ & 6,2228 & 54,4068 & 42,5067 \\
\hline $\begin{array}{l}\text { Penghalusan Eksponensial Ganda (Double } \\
\text { Exponentian Smoothing) }\end{array}$ & 6,5391 & 57,2116 & 56,458 \\
\hline
\end{tabular}

Berdasarkan Tabel 4.6, penjualan produk suplemen Green World pada tokopedia yang dianalisis dengan Minitab 18 dengan metode peramalan Rataan Bergerak (Moving Average) memiliki nilai MSE terkecil $(40,4167)$ dibandingkan dengan metode peramalan lainnya. 
Peramalan penjualan suplemen Green World untuk 15 periode kedepan di tokopedia, dianalisis menggunakan metode peramalan Rataan Bergerak (Moving Average).

Tabel 3.7 Ramalan penjualan produk suplemen Green World pada blibli dengan metode Moving Average

\begin{tabular}{|c|l|c|}
\hline Periode & \multicolumn{1}{|c|}{ Bulan } & Peramalan Penjualan \\
\hline 20 & Agustus 2017 & 16,3333 \\
\hline 21 & September 2017 & 16,3333 \\
\hline 22 & Oktober 2017 & 16,3333 \\
\hline 23 & November 2017 & 16,3333 \\
\hline 24 & Desember 2017 & 16,3333 \\
\hline 25 & Januari 2018 & 16,3333 \\
\hline 26 & Februari 2018 & 16,3333 \\
\hline 27 & Maret 2018 & 16,3333 \\
\hline 28 & April 2018 & 16,3333 \\
\hline 29 & Mei 2018 & 16,3333 \\
\hline 30 & Juni 2018 & 16,3333 \\
\hline 31 & Juli 2018 & 16,3333 \\
\hline 32 & Agustus 2018 & 16,3333 \\
\hline 33 & September 2018 & 16,3333 \\
\hline 34 & Oktober 2018 & 16,3333 \\
\hline
\end{tabular}




\subsubsection{Hasil Perhitungan pada E-marketplace}

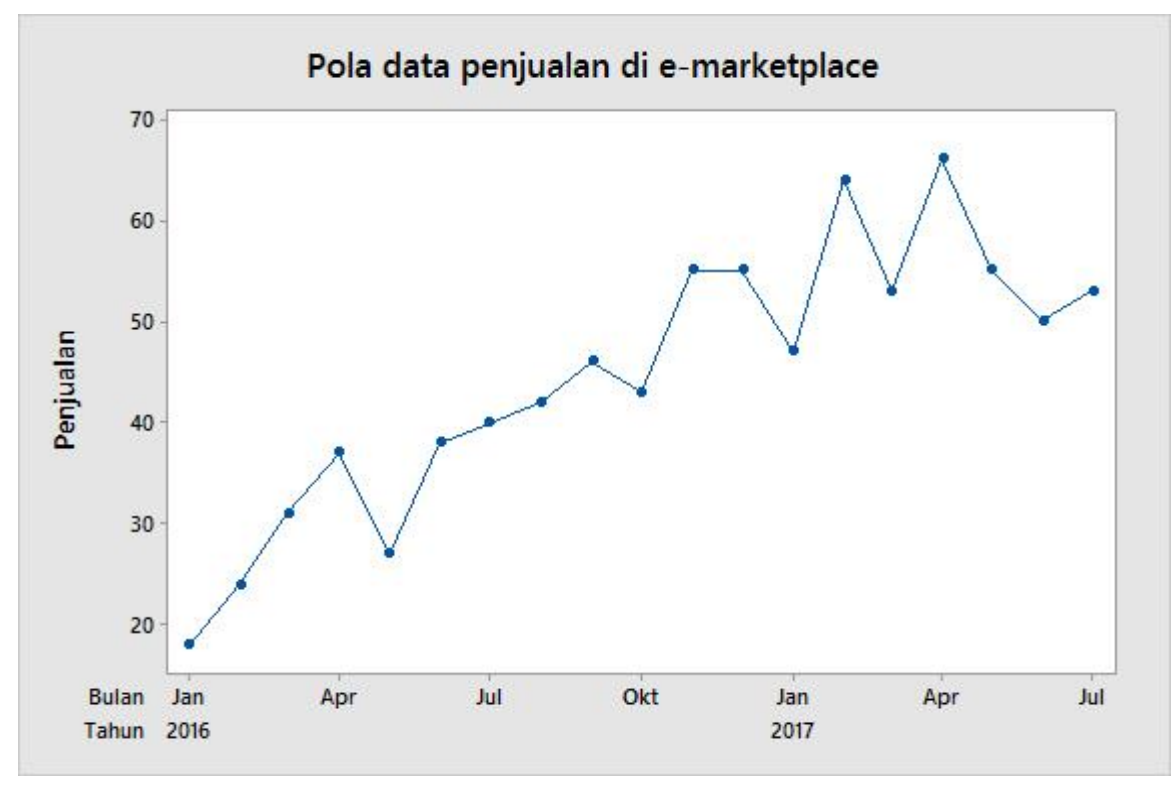

Gambar 3.4 Pola data penjualan pada E-marketplace

Berdasarkan data penjualan pada e-marketplace, dilakukan identifikasi kesalahan peramalan dengan metode rataan bergerak (moving average), penghalusan eksponensial tunggal (single exponential smoothing), dan penghalusan eksponensial ganda (double exponential smoothing). Perhitungan masing-masing metode dengan menggunakan software MINITAB 18 terdapat pada Lampiran.

Tabel 4.8 Analisa Kesalahan Peramalan Penjualan di E-marketplace

\begin{tabular}{|l|c|c|c|}
\hline \multicolumn{1}{|c|}{ Metode } & MAD & MSE & MAPE \\
\hline Rataan Bergerak (Moving Average) & 6,7292 & 57,1597 & 14,1294 \\
\hline $\begin{array}{l}\text { Penghalusan Eksponensial Tunggal (Single } \\
\text { Exponentian Smoothing) }\end{array}$ & 8,2342 & 97,8071 & 19,5173 \\
\hline $\begin{array}{l}\text { Penghalusan Eksponensial Ganda (Double } \\
\text { Exponentian Smoothing) }\end{array}$ & 6,2676 & 50,0011 & 15,1597 \\
\hline
\end{tabular}

Berdasarkan Tabel 4.8, penjualan produk suplemen Green World pada $e$ marketplace yang dianalisis dengan Minitab 18 dengan metode peramalan Penghalusan Eksponensial Ganda (Double Exponentian Smoothing) memiliki nilai MSE terkecil $(50,0011)$ dibandingkan dengan metode peramalan lainnya. 
Peramalan penjualan suplemen Green World untuk 15 periode kedepan di $e$ marketplace, dianalisis menggunakan metode peramalan Penghalusan Eksponensial Ganda (Double Exponentian Smoothing).

Tabel 4.91 Ramalan penjualan produk suplemen Green World pada e-marketplace dengan metode Double Exponentian Smoothing

\begin{tabular}{|c|l|c|}
\hline Periode & \multicolumn{1}{|c|}{ Bulan } & Peramalan Penjualan \\
\hline 20 & Agustus 2017 & 62,8403 \\
\hline 21 & September 2017 & 64,0901 \\
\hline 22 & Oktober 2017 & 65,3399 \\
\hline 23 & November 2017 & 66,5897 \\
\hline 24 & Desember 2017 & 67,8394 \\
\hline 25 & Januari 2018 & 69,0892 \\
\hline 26 & Februari 2018 & 70,3390 \\
\hline 27 & Maret 2018 & 71,5888 \\
\hline 28 & April 2018 & 72,8385 \\
\hline 29 & Mei 2018 & 74,0883 \\
\hline 30 & Juni 2018 & 75,3381 \\
\hline 31 & Juli 2018 & 76,5878 \\
\hline 32 & Agustus 2018 & 77,8376 \\
\hline 33 & September 2018 & 79,0874 \\
\hline 34 & Oktober 2018 & 80,3372 \\
\hline
\end{tabular}

\subsection{Pembahasan}

\subsubsection{Pembahasan Hasil Perhitungan pada Tokopedia}

Dari gambar 4.1 diketahui bahwa penjualan di tokopedia memiliki pola acak, penjualan terendah terdapat pada bulan Februari 2016 dan penjualan tertinggi pada bulan Februari 2017. Penjualan pada bulan Februari 2017 mengalami peningkatan yang sangat signifikan dan langsung megalami penurunan signifikan pada bulan selanjutnya. Peramalan penjualan suplemen Green World untuk 15 periode kedepan di tokopedia, dianalisis menggunakan metode peramalan Penghalusan Eksponensial Ganda (Double Exponentian Smoothing) dengan nilai $\alpha=0,2$, dan $\beta=0,2$. 
Dari tabel 4.3 ternyata hasil peramalan yang diperoleh dari jumlah penjualan setiap bulannya mengalami peningkatan, yaitu hasil peramalan bulan Agustus 2017 (22 produk) meningkat pada bulan September 2017 (23 produk) dan terus mengalami peningkatan hingga tercapai peramalan penjualan tertinggi pada periode 15 yaitu 31 produk pada bulan Oktober 2018.

\subsubsection{Pembahasan Hasil Perhitungan pada Bukalapak}

Dari gambar 4.2 diketahui bahwa penjualan di bukalapak memiliki pola tren meningkat, penjualan terendah terdapat pada bulan Januari 2016 dan penjualan tertinggi pada bulan Februari dan Maret 2017. Penjualan pada bulan Februari 2017 mengalami peningkatan yang sangat signifikan, lalu tetap pada bulan selanjutnya, dan megalami penurunan pada bulan April 2017. Peramalan penjualan suplemen Green World untuk 15 periode kedepan di bukalapak, dianalisis menggunakan metode peramalan Penghalusan Eksponensial Ganda (Double Exponentian Smoothing) dengan nilai $\alpha=$ 0,2 , dan $\beta=0,2$.

Dari tabel 4.5 ternyata hasil peramalan yang diperoleh dari jumlah penjualan setiap bulannya mengalami peningkatan, yaitu hasil peramalan bulan Agustus 2017 (18 produk) meningkat pada bulan September 2017 (19 produk) dan terus mengalami peningkatan hingga tercapai peramalan penjualan tertinggi pada periode 15 yaitu 28 produk pada bulan Oktober 2018.

\subsubsection{Pembahasan Hasil Perhitungan pada Blibli}

Dari gambar 4.3 diketahui bahwa penjualan di blibli memiliki pola acak, penjualan terendah terdapat pada bulan Januari dan Mei 2016 dan penjualan tertinggi pada bulan November dan Desember 2016. Penjualan dari bulan Mei hingga bulan November 2016 menunjukkan tren naik lalu kembali turun pada bulan Januari hingga Februari 2017. Peramalan penjualan suplemen Green World untuk 15 periode kedepan di blibli, dianalisis menggunakan metode peramalan Rataan Bergerak (Moving Average) dengan panjang rataan 3 .

Dari tabel 4.7 ternyata hasil peramalan yang diperoleh dari jumlah penjualan setiap bulannya tidak mengalami peningkatan ataupun penurunan, yaitu tetap 17 produk dari periode 1 bulan Agustus 2017 hingga periode 15 pada bulan Oktober 2018.

\subsubsection{Pembahasan Hasil Perhitungan pada $E$-marketplace}

Dari gambar 4.4 diketahui bahwa penjualan di e-marketplace memiliki pola tren meningkat, penjualan terendah terdapat pada bulan Januari 2016 dan penjualan tertinggi pada bulan April 2017. Penjualan cenderung mengalami peningkatan yang konstan, tidak menunjukkan ada penurunan ataupun peningkatan yang signifikan. Peramalan 
penjualan suplemen Green World untuk 15 periode kedepan di e-marketplace, dianalisis menggunakan metode peramalan Penghalusan Eksponensial Ganda (Double Exponentian Smoothing) dengan nilai $\alpha=0,2$, dan $\beta=0,2$.

Dari tabel 4.9 ternyata hasil peramalan yang diperoleh dari jumlah penjualan setiap bulannya mengalami peningkatan, yaitu hasil peramalan bulan Agustus 2017 (63 produk) meningkat pada bulan September 2017 (64 produk) dan terus mengalami peningkatan hingga tercapai peramalan penjualan tertinggi pada periode 15 yaitu 81 produk pada bulan Oktober 2018.

\section{KESIMPULAN DAN SARAN}

\subsection{Kesimpulan}

Dari hasil analisis peramalan penjualan produk suplemen Green World pada $E$ marketplace di Stokis Alam Sutera dari bulan Januari 2016 sampai Juli 2017 untuk 15 periode, didapat kesimpulan sebagai berikut :

1. Pola data penjualan produk suplemen Green World pada e-marketplace dari bulan Januari 2016 sampai Juli 2017 menunjukkan tren naik. Penjualan pada tokopedia dan blibli menunjukkan pola acak dan penjualan pada bukalapak menunjukkan tren naik.

2. Dari hasil perhitungan tingkat kesalahan penjualan produk suplemen Green World yang dianalisis dengan Minitab 18, analisis penjualan pada tokopedia lebih sesuai dengan metode peramalan Penghalusan Eksponensial Ganda (Double Exponentian Smoothing) yang memiliki nilai MSE terkecil (22,9827), pada bukalapak lebih sesuai dengan metode peramalan Penghalusan Eksponensial Ganda (Double Exponentian Smoothing) yang memiliki nilai MSE terkecil $(11,6920)$, pada blibli lebih sesuai dengan metode peramalan Rataan Bergerak (Moving Average) yang memiliki nilai MSE terkecil (40,4167), dan untuk keseluruhan penjualan pada emarketplace lebih sesuai dengan metode peramalan Penghalusan Eksponensial Ganda (Double Exponentian Smoothing) yang memiliki nilai MSE terkecil $(50,0011)$ dibandingkan dengan metode peramalan lainnya.

3. Hasil peramalan penjualan produk suplemen Green World pada $e$ marketplace dari Januari 2016 sampai Juli 2017 cukup bervariasi. Peramalan penjualan pada tokopedia dan bukalapak mengalami peningkatan dimana hasil ramalan tertinggi terdapat pada periode 15 dengan penjualan 31 produk di tokopedia dan 28 produk di bukalapak. Ramalan penjualan di blibli menunjukkan angka yang tetap dari periode 1 hingga 15 yaitu 17 produk. Hasil ramalan penjualan secara keseluruhan pada e-marketplace 
mengalami peningkatan dimana hasil ramalan tertinggi terdapat pada periode 15 dengan penjualan 81 produk.

\subsection{Saran}

Dari hasil analisis peramalan penjualan produk suplemen Green World pada $E$ marketplace di Stokis Alam Sutera dari bulan Januari 2016 sampai Juli 2017 untuk 15 periode, penulis memberi saran :

1. Perusahaan sebaiknya melakukan peramalan secara berkala (misalnya 3 atau 6 bulan sekali), agar memudahkan menetapkan target penjualan, maupun target lainnya untuk meningkatkan keuntungan perusahaan.

2. Perusahaan sebaiknya memilih metode terbaik yang tingkat keakuratannya paling tinggi (misalnya metode Penghalusan Eksponensial Ganda sebagai metode terbaik di tokopedia), sehingga hasil peramalan tidak berbeda jauh dengan realisasi dan dapat mengurangi ketidakpastian yang terjadi pada masa mendatang.

3. Perusahaan harus teliti dan cermat dalam melakukan peramalan penjualan (misalnya melihat output pada computer), karena hasil peramalan yang dilakukan akan digunakan sebagai dasar penyusunan strategi produksi, pemasaran maupun keuangan di masa mendatang.

\section{DAFTAR PUSTAKA}

Heeren, Rick, (2010), Marketplace Miracle, Andi Publisher, Yogyakarta

Makridakis, Spyros, Steven C, Wheelwright, and Victor E, (1999), Metode Aplikasi Dan Peramalan, Edisi I, Erlangga, Jakarta.

Mishra, Kamala Kanta, http://www.datasciencecentral.com/profiles/blogs/ selectingforecasting-methods-in-data-science, Februari, 2017

Pratama, I Putu Agus Eka, (2015), E-Commerce E-Business Dan Mobile Commerce, Informatika, Bandung.

Riyanto, Teguh, https://zahiraccounting.com/id/blog/mengenal-marketplace-kelebihandan-kekurangannya/, Desember, 2015

Santoso, Singgih, (2009), Business Forecasting : Metode Peramalan Bisnis Masa Kini dengan Minitab dan SPSS, Elex Media Komputindo, Jakarta.

Subagyo, Pangestu, (2013), Forecasting Konsep dan Aplikasi, Cetakan I, BPFE, Yogyakarta.

Yanto, Apri, https://id.techinasia.com/talk/populernya-situs-marketplace-di-indonesia, Februari, 2016 